\title{
5-Fluorouracil "Chemowraps" in the Treatment of Multiple Actinic Keratoses: A Norwich Experience
}

Peter K. C. Goon (D) - Rachel Clegg • Adrian S. W. Yong • Ava S. W. Lee •

Kevin Y. C. Lee · Nick J. Levell · Eunice K. H. Tan · Syed N. Shah

To view enhanced content go to www.dermtherapy-open.com

Received: July 26, 2015 / Published online: August 25, 2015

(C) The Author(s) 2015. This article is published with open access at Springerlink.com

\section{ABSTRACT}

Introduction: Topical 5-fluorouracil (5-FU) has been used to treat actinic keratosis for decades. It has been an important and effective treatment which the patient can self-administer, but is limited by the surface area of skin to be treated (according to the manufacturer's guidelines) of $500 \mathrm{~cm}^{2}$. Other topical treatments can be painful, or require hospital/health care professional input. The use of 5-FU under occlusion (chemowraps) for large areas of sun-damaged skin on the arms or legs has been described and is a potentially useful

Electronic supplementary material The online version of this article (doi:10.1007/s13555-015-0082-5) contains supplementary material, which is available to authorized users.

P. K. C. Goon $(\bowtie) \cdot$ R. Clegg · A. S. W. Yong ·

A. S. W. Lee · K. Y. C. Lee - N. J. Levell ·

E. K. H. Tan - S. N. Shah

Department of Dermatology, Norfolk and Norwich

University Hospital, Norwich, UK

e-mail: peter.goon@nhs.net

Present Address:

A. S. W. Yong

Department of Dermatology, University of Malaya,

Kuala Lumpur, Malaysia treatment option. We describe our experiences with this technique in the Norfolk and Norwich University Hospital Dermatology Department (Norwich, UK).

Methods: Five patients were recruited into this pilot study. Topical 5-FU was applied to sun-damaged limbs under occlusion, and reviewed weekly for response, and local or systemic side effects. Treatment duration was 12-14 weeks. Clinical photography was undertaken prior to, during, and after treatment to document response.

Results: We show that there was substantial clinical improvement in the treated skin in our patients. Experienced dermatologists reviewed all the patients, and documented the changes photographically, and by counting lesions. All patients were satisfied with their treatment regimen, and also with the end result; although two did not complete the treatment regimen due to complications not directly attributable to the treatment.

Conclusion: Topical 5-FU under occlusion (chemowraps) may be a valid treatment option for large areas of sun-damaged skin with field cancerization changes, due to low systemic and local toxicity, and acceptability to patients. 
Keywords: Chemowraps; Field cancerization; Sun-damaged skin; Topical 5-fluorouracil

\section{INTRODUCTION}

5-Fluorouracil (5-FU) has been used to treat actinic or solar keratoses for over 50 years. Its main mode of action is due to its structure (a pyrimidine analog) and it binds irreversibly to thymidylate synthetase. $5-\mathrm{FU}$ in a $5 \% \mathrm{w} / \mathrm{w}$ formulation (Efudix $^{\circledR}$, Meda Pharmaceuticals Ltd., Bishop's Stortford, UK) is a standard topical treatment in the UK for precancerous conditions such as Bowen's disease, actinic keratosis, or superficial basal cell carcinoma (SBCC). The efficacy of treatment and durability of response for actinic keratoses treatment have recently been demonstrated [1].

Sun-damaged skin may exhibit "field cancerization", that is, a wide area of skin with dysplastic epithelium and a high risk of multiple primary cancers arising separately from this large background area of abnormal cells. Treatment of large surface areas is challenging. Treatments available include: photodynamic therapy (PDT), which is painful and expensive, and so is often inappropriate in an era of National Health Service (NHS) financial austerity; cryotherapy [2], which requires skill and is not suitable for large areas due to pain and risk of ulceration in elderly, edematous legs with poor peripheral vascular supply; and $\mathrm{CO}_{2}$ laser resurfacing and chemical peels, which are not available in most UK NHS hospitals. Furthermore, other topical treatments available include: Imiquimod 5\% cream, colchicine, ingenol mebutate, and diclofenac, although data on their efficacy for patients with large areas of disease are scanty.

The standard treatment regimen for $5-\mathrm{FU}$ is for topical application to the lesions and surrounding area, once or twice a day, for 3-4 weeks. The recommended (according to the manufacturer's guidelines) maximum treated surface area of skin at one time is $500 \mathrm{~cm}^{2}$. Two groups have reported the use of 5-FU topically under occlusion (chemowraps) to treat diffuse and heavily ultraviolet (UV)-damaged legs in the elderly population $[3,4]$. In this pilot study, we describe our initial experiences with five patients treated with 5-FU chemowraps for diffusely actinic-damaged limbs.

\section{METHODS}

All procedures followed were in accordance with the ethical standards of the responsible committee on human experimentation (institutional and national) and with the Helsinki Declaration of 1964, as revised in 2013. Informed consent was obtained from all patients for being included in the study. All patients were seen in the Norfolk and Norwich University Hospital's Department of Dermatology (Norwich, UK).

Patients were informed that topical treatment with 5-FU in this way is an off-label treatment. Five unselected patients with diffuse and heavily UV-damaged limbs consented to treatment. Clinical photography was used to document the lesions and extent of disease prior to, during, and after treatment. Twenty grams of 5-FU was applied to cover each leg, with occlusion using zinc oxide and crepe bandages at each weekly visit. In our patient with arm lesions, $10 \mathrm{~g}$ of 5-FU was applied to cover each arm, again under occlusion. Occlusion was maintained for the week, and patients were reviewed weekly for response, clinical toxicity, and further treatment applications. All patients were reviewed by 
experienced dermatologists and a specialist nurse. Lesions were noted for their position, and counted, prior to photography. Any lesion suspicious for squamous cell carcinoma (SCC) was excised for histopathology.

Patients were questioned informally at the end of treatment about their satisfaction with their treatment and the outcomes (formal patient satisfaction questionnaires not undertaken).

\section{RESULTS}

Table 1 shows details of the five patients involved in the 5-FU "chemowrap" treatment. All patients were subjected to weekly reviews with clinical monitoring throughout. Potential side effects of toxicity that were monitored for included neutropenia, mucositis, and diarrhea; however, no side effects were detected. Table 1 clearly documents our patients' details on duration of treatment, treatment breaks, completion of treatment, toxicity of treatment, and previous treatments prior to commencement of chemowraps. Two patients did not complete the regimen of treatment, both due to non-treatment-related complications. See Fig. 1 for photographic comparisons.

\section{DISCUSSION}

We have presented here the results of our experiences with chemowraps in a small cohort of patients. The results have been very encouraging. All patients who completed the regimen showed objective evidence of improvement, with a decrease in the numbers of actinic keratoses or a reduction in the size of lesions. Close monitoring of patients for

Table 1 5-FU chemowrap patients: results

\begin{tabular}{|c|c|c|c|c|c|c|}
\hline $\begin{array}{l}\text { Patient } \\
\text { number }\end{array}$ & $\begin{array}{l}\text { Age } \\
\text { (years)/gender }\end{array}$ & $\begin{array}{l}\text { Treatment } \\
\text { period/area }\end{array}$ & $\begin{array}{l}\text { Treatment } \\
\text { breaks }\end{array}$ & $\begin{array}{l}\text { Treatment completed/ } \\
\text { improvement }\end{array}$ & $\begin{array}{l}\text { Side } \\
\text { effects } \\
\text { of toxicity }\end{array}$ & $\begin{array}{l}\text { Previous } \\
\text { treatments }\end{array}$ \\
\hline 1 & $86 / \mathrm{F}$ & $\begin{array}{l}14 \text { weeks/bilateral } \\
\text { legs }\end{array}$ & $\begin{array}{l}\text { Weeks } 6 \\
\text { and } 12\end{array}$ & Yes/yes & None & $\begin{array}{l}\text { Cryotherapy, } \\
\text { 5-FU, 5\% } \\
\text { imiquimod }\end{array}$ \\
\hline 2 & $53 / F$ & $\begin{array}{l}12 \text { weeks/bilateral } \\
\text { arms }\end{array}$ & Week 6 & Yes/yes & None & $\begin{array}{l}\text { Cryotherapy, } \\
\text { 5-FU, 5\% } \\
\text { imiquimod, } \\
\text { PDT }\end{array}$ \\
\hline 3 & $67 / F$ & $\begin{array}{l}14 \text { weeks/bilateral } \\
\text { legs }\end{array}$ & Week 10 & Yes/yes & None & $\begin{array}{l}\text { Cryotherapy, } \\
\text { 5-FU }\end{array}$ \\
\hline 4 & $80 / \mathrm{F}$ & $\begin{array}{l}3 \text { weeks/bilateral } \\
\text { legs }\end{array}$ & None & $\begin{array}{l}\text { No, stopped early due to } \\
\text { discomfort with } \\
\text { pre-existing leg edema/no }\end{array}$ & None & $\begin{array}{l}\text { Cryotherapy, } \\
\text { 5-FU, PDT }\end{array}$ \\
\hline 5 & $70 / \mathrm{F}$ & $\begin{array}{l}6 \text { weeks/bilateral } \\
\text { legs }\end{array}$ & Week 4 & $\begin{array}{l}\text { No, stopped early due to } \\
\text { urinary tract infection/no }\end{array}$ & None & $\begin{array}{l}\text { Cryotherapy, } \\
\text { 5-FU }\end{array}$ \\
\hline
\end{tabular}

5-FU 5-fluorouracil, $F$ female, $P D T$ photodynamic therapy 


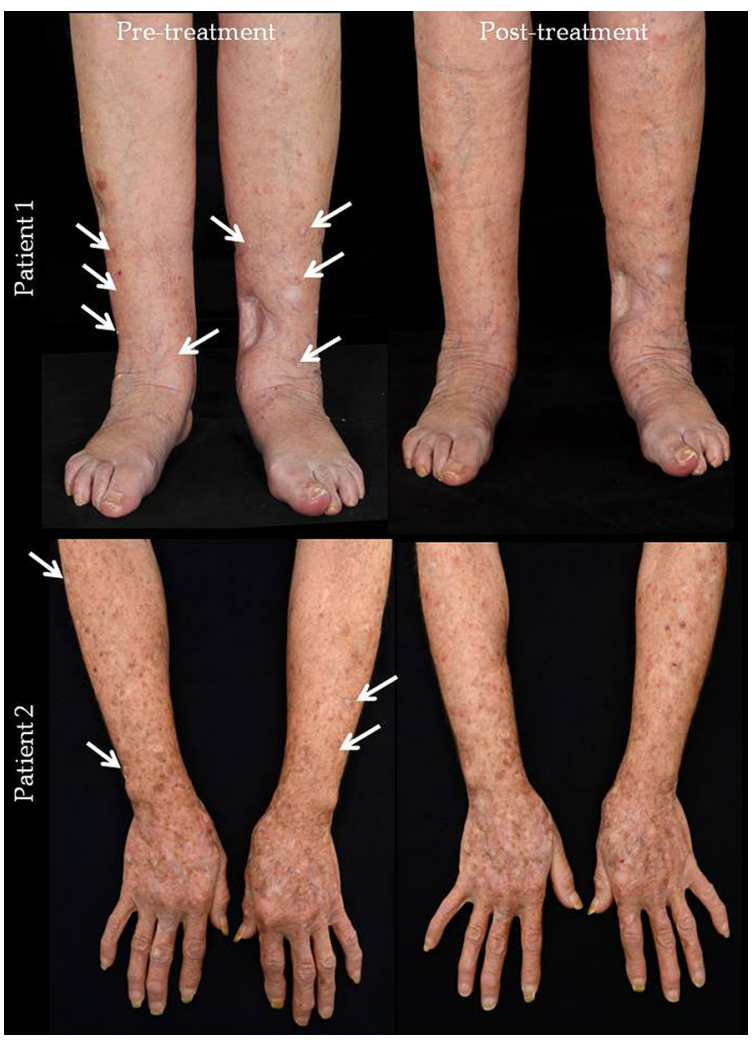

Fig. 1 Photos of two representative patients who completed chemowrap treatment. White arrows point to actinic keratoses or Bowenoid lesions which have evidently improved after treatment, by resolving completely, or diminishing in size and thickness

toxicity did not reveal any adverse events. Two patients did not complete their treatment, due to non-treatment-related complications. All patients reported satisfaction with the treatment regimen and their outcomes, even if they did not complete treatment.

Mann et al. [3] described their experiences of treating three patients (but representative of over 200 patients) with significant actinic damage with 5-FU chemowraps. Only two patients reported hair loss and possible contact allergy to 5-FU, and there were no serious adverse events. It was reported that skin irritation was minimal compared with the standard regimen of once or twice daily application of 5-FU. Most patients reported satisfaction with the treatment, although no formal survey was undertaken. Tallon and Turnbull [4] reported excellent response rates and patient satisfaction in their cohort of five patients.

Systemic toxicity with 5-FU is a primary concern. It is known that the rate-limiting enzyme dihydropyrimidine dehydrogenase (DPD), which is encoded by the DPYD gene, deactivates more than $80 \%$ of standard oral doses of 5-FU and its prodrug, capecitabine [5]. True (complete) deficiency of DPD is found in approximately $5 \%$ of the population, and drug half-life is prolonged, with accumulation of drug and subsequent toxicity [5]. A further $3-5 \%$ of the population have variant mutations in $D P Y D$, which decrease enzymatic activity, and are more susceptible to toxicity [6]. Although our patients only received topical 5-FU, we monitored them closely for clinical signs of systemic toxicity such as neutropenia, diarrhea, and mucositis. None of our patients demonstrated any adverse events.

Local experiences with these 5-FU chemowraps have been positive. There is a dearth of effective, well-tolerated, and safe treatment options available for patients with diffuse actinic damage on their limbs. A recent randomized-controlled clinical trial demonstrated superiority of imiquimod 5\% treatment to 5-FU topically (standard regimen) or cryosurgery [7]. It is interesting to speculate that treatment under occlusion with topical 5-FU would be more successful than the standard regimen. Potential advantages of chemowraps compared to some of the other topical treatments include the ability to treat large surface areas and the lack of pain or discomfort so far.

Our experiences with 5-FU chemowraps suggest that this off-label treatment modality is a useful option for patients with large areas of 
diffuse actinic damage. There appears to be a low risk of systemic or local toxicity with this regimen, but since the majority of patients with large areas of sun-damaged skin are the elderly, consideration of co-morbidities or unstable medical conditions are highly important. The data suggest that a properly randomized, blinded, and controlled clinical trial is required to establish the true efficacy of chemowraps.

\section{ACKNOWLEDGMENTS}

No funding or sponsorship was received for this study or publication of this article. All named authors meet the International Committee of Medical Journal Editors (ICMJE) criteria for authorship for this manuscript, take responsibility for the integrity of the work as a whole, and have given final approval to the version to be published.

Conflict of interest. Peter K. C. Goon, Rachel Clegg, Adrian S. W. Yong, Ava S. W. Lee, Kevin Y. C. Lee, Nick J. Levell, Eunice K. H. Tan, and Syed N. Shah have nothing to disclose.

Compliance with ethics guidelines. All procedures followed were in accordance with the ethical standards of the responsible committee on human experimentation (institutional and national) and with the Helsinki Declaration of 1964, as revised in 2013. Informed consent was obtained from all patients for being included in the study.

Open Access. This article is distributed under the terms of the Creative Commons
Attribution-NonCommercial 4.0 International License (http://creativecommons.org/licenses/ by-nc/4.0/), which permits any noncommercial use, distribution, and reproduction in any medium, provided you give appropriate credit to the original author(s) and the source, provide a link to the Creative Commons license, and indicate if changes were made.

\section{REFERENCES}

1. Pomerantz H, Hogan D, Eilers D, et al. Long-term efficacy of topical fluorouracil cream, 5\%, for treating actinic keratosis: a randomized clinical trial. JAMA Dermatol. 2015. doi:10.1001/jamadermatol.2015. 0502.

2. Chiarello SE. Cryopeeling (extensive cryosurgery) for treatment of actinic keratoses: an update and comparison. Dermatol Surg. 2000;26(8):728-32.

3. Mann M, Berk DR, Petersen J. Chemowraps as an adjuvant to surgery for patients with diffuse squamous cell carcinoma of the extremities. J Drugs Dermatol. 2008;7(7):685-8.

4. Tallon B, Turnbull N. 5\% fluorouracil chemowraps in the management of widespread lower leg solar keratoses and squamous cell carcinoma. Australas J Dermatol. 2013;54(4):313-6.

5. Lee A, Ezzeldin $\mathrm{H}$, Fourie J, Diasio R. Dihydropyrimidine dehydrogenase deficiency: impact of pharmacogenetics on 5-fluorouracil therapy. Clin Adv Hematol Oncol. 2004;2(8):527-32.

6. Amstutz U, Froehlich TK, Largiader CR. Dihydropyrimidine dehydrogenase gene as a major predictor of severe 5-fluorouracil toxicity. Pharmacogenomics. 2011;12(9):1321-36.

7. Krawtchenko N, Roewert-Huber J, Ulrich M, Mann I, Sterry W, Stockfleth E. A randomised study of topical $5 \%$ imiquimod vs. topical 5-fluorouracil vs. cryosurgery in immunocompetent patients with actinic keratoses: a comparison of clinical and histological outcomes including 1-year follow-up. $\mathrm{Br}$ J Dermatol. 2007;157(Suppl 2):34-40. 